Dorota Otapowicz

Wydzią Pedagogiki i Psychologi

UNIWERSYTET W BIAŁYMSTOKU

E-MAIL: DOROTA667@WP.PL

AgNieszKa SaKowiCz-Boboryko

Wydziae Pedagogiki i Psychologit

UNIWERSYTET W BIAEYMSTOKU

E_MAIL: AGNIESZKA.SAKOWICZ@UWB.EDU.PL

Dorota WyrzyKowsKa-Koda

Wydziat Pedagogiki i Psychologi

UNIWERSYTET W BIAŁYMSTOKU

E-MAIL: D.KODA@UWB.EDU.PL

\title{
NIEPEŁNOSPRAWNOŚĆ A JAKOŚĆ ŻYCIA RODZINY
}

\section{Wstęp}

Badania dotyczące jakości życia rodziny należą do zagadnień złożonych, w których krzyżują się dyscyplinarne ujęcia oraz pola badawczych zainteresowań. Samo pojęcie ,jakość życia”, intuicyjnie zrozumiałe dla każdego, jest terminem wieloaspektowym, nieposiadającym jednoznacznej definicji. Przez psychologów jest traktowane m.in. jako satysfakcja osobista lub poczucie szczęścia w tych dziedzinach życia, które jednostka personalnie uznaje za ważne [Dziurowicz-Kozłowska, 2002: 77] kompleksowy sposób oceniania przez jednostkę jej zdrowia fizycznego, stanu emocjonalnego, samodzielności w życiu i stopnia niezależności od otoczenia, a także osobistych wierzeń i przekonań [Tobiasz-Adamczyk, 2000: 239]. W medycynie zwraca się uwagę na funkcjonalną sprawność ludzi. Przyjmuje się, że możliwości samodzielnego funkcjonowania w życiu i realizowanie posiadanych szans rozwojowych to istota jakości życia [Majkowicz, Nowicki, Samet, 2004: 9]. Wśród socjologów panuje zgodność co do poglądu, iż jakość życia odnosi się do faktu za- 
spokojenia potrzeb, a przy opisie zakresu pojęcia „jakość życia” ważna jest zarówno analiza determinantów obiektywnych, jak i subiektywnych. W skład wyznaczników obiektywnej jakości życia wchodzą: sytuacja ekonomiczna, warunki mieszkaniowe, środowisko naturalne i inne. Z kolei subiektywną ocenę stanowią: samopoczucie, ocena ogólnych i specyficznych warunków życia ujmowana w kategoriach zadowolenia, szczęścia, lęku.

Niepełnosprawność dziecka jest tym czynnikiem, który powoduje zmiany w funkcjonowaniu całego systemu rodzinnego. W ujęciu ekosystemowym życia rodzinnego niepełnosprawność nie jest bowiem problemem wyłącznie dziecka, ale przez sieć wzajemnych powiązań tworzy sytuację, w której uczestniczy również jego najbliższe otoczenie. „Cała rodzina jest uwikłana w problem niepełnej sprawności i dotknięta jest nią we wszystkich swych funkcjach, we wszystkich wymiarach swej egzystencji i w codziennym życiu" [Kawczyńska-Butrym, 1994: 34]. W analizach jakości życia rodzin [zob. Firkowska-Mankiewicz, 2001; Ostrzyżek, 2012; Sadowska, 2006] powtarza się twierdzenie, iż niepełnosprawność tworzy sytuację trudną pod względem emocjonalnym, społecznym, obniża poziom jakości życia rodzinnego w wymiarze ekonomicznym, kulturowym, zdrowotnym. W systemie rodzinnym następuje istotne przeformowanie charakterystyki wewnętrznej, dochodzi do intensywnych przeżyć wewnętrznych u wszystkich jego członków, co w konsekwencji rzutuje na zmianę w hierarchii realizowanych wartości w rodzinie, na zmianę strategii podejmowanych w niej działań i nastrój towarzyszący wszelkiej aktywności rodziny. Wszyscy członkowie rodziny znajdują się w nowym położeniu, wymagającym od nich podejmowania złożonych decyzji, modyfikacji dotychczas pełnionych ról, których wymiar pozostaje w pewnej sprzeczności z ich dotychczasowymi doświadczeniami.

Każdej zatem rodzinie wychowującej dziecko niepełnosprawne, nawet najbardziej spójnej wewnętrznie, zintegrowanej emocjonalnie, niezbędne jest wsparcie społeczne. Pożądana jest sytuacja, w której otrzymywane wsparcie jest dostosowane do indywidualnych potrzeb rodziny, jest trafne ilościowo i jakościowo.

Zagadnienie jakości życia rodzin z dzieckiem niepełnosprawnym uczyniono przedmiotem badań własnych.

Celem podjętych badań była próba oceny jakości życia rodzin wychowujących dziecko niepełnosprawne, zamieszkujących na terenie województwa podlaskiego. Dokonano także analizy uzyskanych wyników pod kątem potrzeb wsparcia społecznego badanych rodzin w kontekście jakości ich życia. 


\section{Materiał i metody}

Dane uzyskano za pomocą wywiadu przeprowadzonego $\mathrm{z}$ matkami dzieci niepełnosprawnych z wykorzystaniem kwestionariusza jakości życia rodziny - Family Quality of Life Survey 2006 (FQOLS-2006), [Brown R. I. Brown, N. T. Baum, Isaacs, Myerscough, Neikrug, Roth, Shearer, Wang, 2006]. Narzędzie powstało w ramach międzynarodowego projektu, w celu oceny sytuacji, zasobów i potrzeb rodzin posiadających niepełnosprawnych członków rodziny. Analiza danych wynikających z wykorzystania FQOLS-2006 zapewnia wgląd w kilka możliwych predyktorów jakości życia rodzinnego i pozwala na wykorzystanie wyników na potrzeby praktyki w rozwiązywaniu problemów takich rodzin [Samuel, Rillotta, Brown, 2012: 1-16].

Badanie obejmuje następujące dziedziny życia: zdrowie rodziny, relacje rodzinne, wsparcie innych, system wartości, kariera zawodowa i przygotowanie do kariery, czas wolny i rekreacja, relacje interpersonalne. Część A kwestionariusza służy do gromadzenia danych jakościowych dotyczących każdej z badanych dziedzin. Na potrzeby prezentowanych badań wykorzystano wyniki zgromadzone za pomocą części B, która zawiera dane ilościowe oraz wybrane wyniki z części A. Oceny dokonywane są za pomocą pięciostopniowej skali Likerta, co pozwala na obliczenie średniej wartości ocen w poszczególnych dziedzinach życia, a także ogólnej oceny jakości życia.

Każdy z obszarów badany jest w relacji z sześcioma kluczowymi pojęciami. W badaniu każdej dziedziny życia uwzględnia się sześć zmiennych: znaczenie (wartość, jaką przypisują rodziny poszczególnym dziedzinom dla jakości życia), szanse (możliwości, jakie dostrzega rodzina w zakresie poszczególnych dziedzin życia), inicjatywa (wysiłki, starania, jakie podejmuje rodzina w poszczególnych obszarach życia), osiągnięcie (aktualna ocena własnej sytuacji), stabilizacja (oczekiwanie zmian własnej sytuacji w najbliższym czasie), satysfakcja (stopień zadowolenia $\mathrm{z}$ aktualnej sytuacji, jakości życia rodziny).

W analizie statystycznej zastosowano obliczenia wartości średniej, odchylenia standardowe, wartości minimalne i maksymalne uzyskanych wyników. Obliczeń dokonano za pomocą programu SPSS.

Badaniami objęto członków rodziny, sprawujących bezpośrednią opiekę nad dzieckiem z niepełnosprawnością. Zazwyczaj sprawują ją matki, stąd $\mathrm{w}$ badanej grupie znalazło się 31matek dzieci z różnymi rodzajami niepełnosprawności: 5 (16\%) - z niepełnosprawnością narządu ruchu, 8 (26\%) - 
104 Dorota Otapowicz, Agnieszka Sakowicz-Boboryko, Dorota Wyrzykowska-Koda

z niepełnosprawnością intelektualną, 7 (23\%), z autyzmem, - 11 (36\%) z niepełnosprawnościami sprzężonymi.

Większość badanych rodzin zamieszkiwała w miastach - 21 (67\%). Przeważały rodziny pełne - 27 (87\%).

\section{Wyniki badań}

Materiał empiryczny dotyczący jakości życia badanych rodzin wychowujących dzieci z niepełnosprawnością zawiera tabela 1.

Tabela 1. Wyniki badania jakości życia rodzin wychowujących dziecko niepełnosprawne w obrębie badanych dziedzin i ogólnej jakości życia

\begin{tabular}{|c|c|c|c|c|}
\hline Dziedziny jakości życia & $\begin{array}{c}\text { Wartość } \\
\text { średnia } \\
(\mathbf{M})\end{array}$ & $\begin{array}{c}\text { Odchylenie } \\
\text { standardowe } \\
\text { (SD) }\end{array}$ & $\begin{array}{c}\text { Wartość } \\
\text { min. }\end{array}$ & $\begin{array}{c}\text { Wartość } \\
\text { maks. }\end{array}$ \\
\hline Zdrowie rodziny & 3,19 & 0,91237 & 1 & 5 \\
\hline Sytuacja finansowa & 3,27 & 0,88723 & 1 & 5 \\
\hline Relacje rodzinne & 3,16 & 0,95936 & 1 & 5 \\
\hline Wsparcie innych osób & $\mathbf{2 , 8 2}$ & 0,78125 & 1 & 5 \\
\hline $\begin{array}{c}\text { Wsparcie w ramach specjali- } \\
\text { stycznych usług }\end{array}$ & $\mathbf{3 , 5 2}$ & 1,08158 & 1 & 5 \\
\hline System wartości & $\mathbf{2 , 5 5}$ & 1,45001 & 0 & 5 \\
\hline $\begin{array}{c}\text { Kariera zawodowa i przygotowa- } \\
\text { nie do kariery }\end{array}$ & 3,22 & 0,86980 & 0 & 5 \\
\hline Czas wolny i rekreacja & 3,16 & 0,71721 & 1 & 5 \\
\hline Interakcje społeczne & 3,01 & 0,71274 & 1 & 5 \\
\hline $\begin{array}{c}\text { Ogólny wynik jakości życia } \\
\text { (dziewięć badanych dziedzin) }\end{array}$ & 3,10 & 1,02290 & 0 & 5 \\
\hline
\end{tabular}

Zaprezentowano w niej średnie wartości uzyskanych wyników, odchylenia standardowe (SD), a także wartości minimalne i maksymalne wyników otrzymanych w obrębie badanych dziedzin.

Uzyskane rezultaty wskazują, że najniższą jakość życia badane rodziny osiągnęły w dziedzinie wsparcia otrzymywanego od innych osób $(\mathrm{M}=2,82)$. Odchylenie standardowe $\mathrm{SD}=0,78$ dowodzi, iż wyniki w poszczególnych 
rodzinach były dość zróżnicowane. Z kolei odnotowana znaczna rozpiętość ocen (od 1 do 5) oznacza, że niektóre rodziny tę dziedzinę życia oceniały wysoko, były jednak także takie, które otrzymywane wsparcie społeczne uznały za bardzo niskie. Równie niekorzystne dane uzyskano w przypadku dziedziny system wartości, gdzie średni wynik wynosił $M=2,55$, przy wysokim zróżnicowaniu $(S D=1,45)$ i wysokiej rozpiętości ocen (od 0 do 5). Najwyższą wartość średnich wyników stwierdzono w zakresie wsparcia w ramach specjalistycznych usług $(\mathrm{M}=3,52)$, przy wysokim zróżnicowaniu $(\mathrm{SD}=1,08)$ i znacznej rozpiętości wyników (od 1 do 5).

Średnie wyniki w pozostałych dziedzinach były zbliżone: od $\mathrm{M}=3,22$ $(\mathrm{SD}=0,86980)$ w zakresie kariery zawodowej i przygotowania do kariery po $\mathrm{M}=3,01$ ( $\mathrm{SD}=0,71274)$ w zakresie interakcji społecznych.

Uzyskane wyniki wskazują zatem na występowanie w badanej zbiorowości rodzin deficytów w ramach systemu wartości i wsparcia otrzymywanego od innych osób, a w przypadku części rodziców - na niedosyt wsparcia $\mathrm{w}$ ramach systemu usług specjalistycznych. Ponadto, niska jakość życia rodzin $\mathrm{z}$ dzieckiem niepełnosprawnym ujawnia się $\mathrm{w}$ większości badanych dziedzin, gdzie wyniki mieszczą się w przedziale od $\mathrm{M}=2,55$ do $\mathrm{M}=3,52$. Ogólny wynik, uwzględniający wartości uzyskane w obrębie wszystkich badanych dziedzin, jest także niski: $\mathrm{M}=3,33$, przy odchyleniu standardowym $\mathrm{SD}=0,89149$. Jeszcze niższa była ogólna ocena własnej jakości życia dokonana przez badane matki $(\mathrm{M}=2,97$; $\mathrm{SD}=0,4819)$, przy czym ogólne zadowolenie z jakości życia rodziny było wyższe $(\mathrm{M}=3,61 ; \mathrm{SD}=0,49514)$.

W dalszej części postępowania badawczego analizie poddano wyniki uzyskane w obrębie badanych dziedzin życia w zakresie charakteryzujących je sześciu szczegółowych zmiennych, tj. znaczenie, szanse, inicjatywa, osiągnięcie, stabilizacja, satysfakcja. Wyniki zaprezentowano w tabeli 2.

Tabela 2. Wyniki badania jakości życia rodzin posiadających niepełnosprawne dziecko w zakresie wartości, szans, wysiłków, osiągnięć, stabilizacji i satysfakcji w poszczególnych dziedzinach życia

\begin{tabular}{|c|c|c|c|c|c|c|}
\hline Dziedziny & $\begin{array}{c}\text { Znacze- } \\
\text { nie }\end{array}$ & Szanse & Inicjatywa & Osiągnięcia & $\begin{array}{c}\text { Stabiliza- } \\
\text { cja }\end{array}$ & Satysfakcja \\
\hline Zdrowie & $\begin{array}{c}5^{*} \\
(0,00)^{\star *}\end{array}$ & $\begin{array}{c}2,97 \\
(1,05647)\end{array}$ & $\begin{array}{c}3,74 \\
(0,77321)\end{array}$ & $\begin{array}{c}3,48 \\
(0,56985)\end{array}$ & $\begin{array}{c}2,97 \\
(0,48193)\end{array}$ & $\begin{array}{c}3,45 \\
(0,67521)\end{array}$ \\
\hline $\begin{array}{c}\text { Sytuacja } \\
\text { finansowa }\end{array}$ & $\begin{array}{c}4,39 \\
(0,49514)\end{array}$ & $\begin{array}{c}3,32 \\
(1,19407)\end{array}$ & $\begin{array}{c}3,81 \\
(0,94585)\end{array}$ & $\begin{array}{c}2,87 \\
(0,34078)\end{array}$ & $\begin{array}{c}2,97 \\
(0,48193)\end{array}$ & $\begin{array}{c}3,35 \\
(0,79785)\end{array}$ \\
\hline
\end{tabular}


106 Dorota Otapowicz, Agnieszka Sakowicz-Boboryko, Dorota Wyrzykowska-Koda

\begin{tabular}{|c|c|c|c|c|c|c|}
\hline $\begin{array}{l}\text { Relacje } \\
\text { rodzinne }\end{array}$ & $\begin{array}{c}4,71 \\
(0,46141)\end{array}$ & $\begin{array}{c}3,58 \\
(0,88597)\end{array}$ & $\begin{array}{c}3,71 \\
(0,64258)\end{array}$ & $\begin{array}{c}4,03 \\
(0,65746)\end{array}$ & $\begin{array}{c}3,10 \\
(0,30054)\end{array}$ & $\begin{array}{c}3,97 \\
(0,54674)\end{array}$ \\
\hline $\begin{array}{c}\text { Wsparcie } \\
\text { innych osób }\end{array}$ & $\begin{array}{c}3,26 \\
(0,77321)\end{array}$ & $\begin{array}{c}3,03 \\
(0,60464)\end{array}$ & $\begin{array}{c}2,45 \\
(0,50588)\end{array}$ & $\begin{array}{c}2,48 \\
(1,36311)\end{array}$ & $\begin{array}{c}3,00 \\
(0,00000)\end{array}$ & $\begin{array}{c}3,48 \\
(0,85131)\end{array}$ \\
\hline $\begin{array}{c}\text { Wsparcie } \\
\text { w ramach } \\
\text { specjalistycz- } \\
\text { nych usług }\end{array}$ & $\begin{array}{c}4,39 \\
(0,55842)\end{array}$ & $\begin{array}{c}2,48 \\
(1,36311)\end{array}$ & $\begin{array}{c}4,32 \\
(0,65254)\end{array}$ & $\begin{array}{c}4,03 \\
(0,65746)\end{array}$ & $\begin{array}{c}3,00 \\
(0,000)\end{array}$ & $\begin{array}{c}3,19 \\
(0,70329)\end{array}$ \\
\hline $\begin{array}{c}\text { System } \\
\text { wartości }\end{array}$ & $\begin{array}{c}3,55 \\
(0,85005)\end{array}$ & $\begin{array}{c}3,23 \\
(0,99028)\end{array}$ & $\begin{array}{c}3,16 \\
(0,68784)\end{array}$ & $\begin{array}{c}3,19 \\
(0,65418)\end{array}$ & $\begin{array}{c}3,00 \\
(0,00000)\end{array}$ & $\begin{array}{c}3,65 \\
(0,48637)\end{array}$ \\
\hline $\begin{array}{c}\text { Kariera } \\
\text { zawodowa } \\
\text { i przygotowa- } \\
\text { nie do kariery }\end{array}$ & $\begin{array}{c}3,71 \\
(1,00643)\end{array}$ & $\begin{array}{c}3,03 \\
(0,75206)\end{array}$ & $\begin{array}{c}2,45 \\
(0,50588))\end{array}$ & $\begin{array}{c}3,29 \\
(0,90161)\end{array}$ & $\begin{array}{c}3,00 \\
(0,0000)\end{array}$ & $\begin{array}{c}3,32 \\
(0,70176)\end{array}$ \\
\hline $\begin{array}{l}\text { Czas wolny } \\
\text { i rekreacja }\end{array}$ & $\begin{array}{c}3,55 \\
(0,72290)\end{array}$ & $\begin{array}{c}2,81 \\
(0,87252)\end{array}$ & $\begin{array}{c}3,06 \\
(0,72735)\end{array}$ & $\begin{array}{c}3,00 \\
(0,77460)\end{array}$ & $\begin{array}{c}3,00 \\
(0,000)\end{array}$ & $\begin{array}{c}3,55 \\
(0,50588)\end{array}$ \\
\hline $\begin{array}{l}\text { Interakcje } \\
\text { społeczne }\end{array}$ & $\begin{array}{c}3,23 \\
(0,84497)\end{array}$ & $\begin{array}{c}2,81 \\
(0,87252)\end{array}$ & $\begin{array}{c}2,81 \\
(0,70329)\end{array}$ & $\begin{array}{c}2,77 \\
(0,66881)\end{array}$ & $\begin{array}{c}3,0 \\
(0,000)\end{array}$ & $\begin{array}{c}3,42 \\
(0,50161)\end{array}$ \\
\hline $\begin{array}{l}\text { Ogółem } \\
\text { (dziewięć } \\
\text { dziedzin) }\end{array}$ & $\begin{array}{c}3,97 \\
(0,92298)\end{array}$ & $\begin{array}{c}2,94 \\
(1,05593)\end{array}$ & $\begin{array}{c}3,34 \\
(0,94893)\end{array}$ & $\begin{array}{c}3,21 \\
(0,83650)\end{array}$ & $\begin{array}{c}3,03 \\
(0,23092)\end{array}$ & $\begin{array}{c}3,49 \\
(0,67777)\end{array}$ \\
\hline
\end{tabular}

${ }^{\star} \mathrm{M}$ - średnie wyniki; ${ }^{*} \mathrm{SD}$ - odchylenie standardowe

Rozkład prezentowanych wyników wskazuje, że zdrowie jest dziedziną, której wszystkie badane osoby przypisywały najwyższe i maksymalne znaczenie dla jakości życia rodziny- $\mathrm{M}=5(\mathrm{SD}=0,00)$. Jednocześnie, pozostałe aspekty tego obszaru oceniane są nisko, zwłaszcza własne szanse na stosowne dbanie o zdrowie- $\mathrm{M}=2,97$ ( $\mathrm{SD}=1,05647)$. Sytuację zdrowotną oceniali jako stabilną, nie licząc na jej poprawę, nie spodziewając się także jej wyraźnego pogorszenia.-M=2,97 ( $\mathrm{SD}=0,48193)$. Nisko też oceniali pozostałe aspekty jakości życia w tym obszarze, poniżej $\mathrm{M}=4,0$. Badani najczęściej wskazywali na następujące przeszkody w dostępie do opieki medycznej: niedostępność określonych usług medycznych w okolicy zamieszkania (90,3\%), długi czas oczekiwania na usługi medyczne (84\%) oraz nieznany sposób leczenia schorzenia (71\%), trudności z transportem (55\%).

Istotne znaczenie przypisują także sytuacji finansowej - $M=4,39$ $(\mathrm{SD}=0,49514)$. Ten obszar także przedstawia się niepokojąco, wszystkie wy- 
niki przyjmują wartość poniżej $M=4,0$. Szczególnie nisko, poniżej $M=3,0$, oceniają aktualne osiągnięcia w tym obszarze $-\mathrm{M}=2,87$ ( $\mathrm{SD}=0,34078)$, nie spodziewając się jednocześnie poprawy tej sytuacji-M=2,97 ( $\mathrm{SD}=0,48193)$. Połowa badanych wskazywało, że po uregulowaniu wydatków pod koniec miesiąca nie zostają im żadne środki do dyspozycji zgodnie $\mathrm{z}$ własnymi życzeniami. Prawie połowa rodzin $-45,2 \%$, na wydatki w związku z potrzebami zdrowotnymi rodziny przeznacza od $25-50 \%$ swojego miesięcznego dochodu, $38.4 \%$ - od 10-25\%. Jedynie 16,1\% badanych rodzin deklaruje kwotę mniejszą niż 10\% miesięcznego dochodu, a 3.2\% nie przeznacza na ten cel żadnych własnych środków.

Ważnym obszarem są także relacje rodzinne - $\mathrm{M}=4,71(\mathrm{SD}=0,46141)$, niestety nisko oceniane przez badanych- wynik ogólny jakości życia w tej dziedzinie $\mathrm{M}=3,16$ ( $\mathrm{SD}=0,95936)$. Wynik satysfakcji wskazuje na ogólne zadowolenie badanych $\mathrm{z}$ tej dziedziny życia $-\mathrm{M}=3,97(\mathrm{SD}=0,54674)$. Analiza danych z części jakościowej ujawniła, że tylko 16,1 \% bardzo dobrze ocenia wzajemną pomoc wśród członków rodziny, a 29,1\% ocenia jako dość dużą. Najczęściej jednak oceniano ją na poziomie średnim,- 38,7\%, a 16,1\% oceniało jako niewielką. Lepiej przedstawiają się ocena wzajemnego wsparcia, przez $16,1 \%$ oceniane jako bardzo duże, najczęściej jako dość duże- 45,2\%. Tylko $16,1 \%$ oceniało je jako niewielkie, a 22,6\% jako średnie. Szczególnie dobrze oceniają swoje relacje rodzinne pod względem zaufania, $29,1 \%$ ocenia, że jest ono bardzo duże, 38,7 \% dość duże. W pozostałych rodzinach oceniane było jako średnie - 29,1\%. Tylko w jednej rodzinie było ono niewielkie.

Wsparcie innych osób to obszar, który można określić jako deficytowy. Badani dość nisko ocenili też jego wartość w jakości życia rodziny$\mathrm{M}=3,26$ ( $\mathrm{SD}=0,77321)$. Szczególnie nisko przedstawia się ich własna inicjatywa w tym zakresie - $\mathrm{M}=2,45(\mathrm{SD}=0,50588)$ jak również ocena szans na zmianę istniejącej sytuacji-M=2,48 ( $\mathrm{SD}=1,36311)$. Praktyczną pomoc ze strony przyjaciół, sąsiadów w opiece nad dzieckiem, w robieniu zakupów czy w pracach związanych z zajmowaniem się domem najczęściej oceniano na poziomie średnim - 46,2 \% lub małym - 30,5\%. Również wsparcie emocjonalne ze strony tych osób oceniane było nisko: $35,5 \%$ oceniło je na poziomie średnim a 45,1\% jako małe.

Dość wysoką wartość przypisują wsparciu w ramach usług specjalistycznych - $\mathrm{M}=4,39(\mathrm{SD}=0,55842)$. Wykazują istotne zaangażowanie $\mathrm{w}$ pozyskiwanie wsparcia specjalistycznego $-\mathrm{M}=4,32(\mathrm{SD}=0,65254)$ i dobrze oceniają osiągnięcia w tym obszarze- $\mathrm{M}=4,03$ ( $\mathrm{SD}=0,65746)$. Mimo to ich satysfakcja pozostaje niska - $\mathrm{M}=3,19(\mathrm{SD}=0,70329)$, ogólnie pesymistycz- 
nie, choć w sposób zróżnicowany, spostrzegają własne możliwości działań w tym obszarze-M=2,48 ( $\mathrm{SD}=1,36311$ ). Prawie połowa badanych matek $(45,1 \%)$ twierdziła, że ma problem $\mathrm{z}$ uzyskaniem wszystkich potrzebnych usług specjalistycznych lub ich zakres jest mniejszy niż oczekiwany.

Pozostałym dziedzinom przypisują niską wartość, o czym świadczą wyniki poniżej 4,0. Ocena ważności systemu wartości wynosiła $\mathrm{M}=3,55$ $(\mathrm{SD}=0,85005)$. Najwyżej ocenioną zmienną charakteryzującą jakość życia w tym obszarze była satysfakcja - M=3,65 ( $\mathrm{SD}=0,48637)$. Wspólnota religijna, duchowa, kulturowa, do której przynależą rodziny, obdarza je akceptacją: $13 \%$ w bardzo dużym stopni, 50\% - w dość dużym. Tylko jedna rodzina nie przynależała do zadanej wspólnoty.

Dość niską wartość przypisywano także karierze zawodowej i przygotowaniu do kariery - $\mathrm{M}=3,55(\mathrm{SD}=0,72290)$. Satysfakcja $\mathrm{w}$ tym obszarze była jeszcze niższa - M=3,32 ( $\mathrm{SD}=0,70176)$. Badane matki szczególnie nisko oceniały własną inicjatywę w tym zakresie - $\mathrm{M}=2,45$ ( $\mathrm{SD}=0,50588)$. Większość z nich pozostawała bierna zawodowo - 67\%, w tym $38,7 \%$ matek zrezygnowało $\mathrm{z}$ pracy całkowicie ze względu na obowiązki związane $\mathrm{z}$ rehabilitacją dziecka. 6,6\% procent matek zrezygnowało z części etatu. Tylko 6,6 \% planuje w przyszłości kontynuację kariery zawodowej lub edukacji.

Niską wartość przypisano także znaczeniu czasu wolnego i rekreacji w jakości życia rodzin - $\mathrm{M}=3,55(\mathrm{SD}=0,72290)$. Podobnie oceniona została także satysfakcja w tym obszarze - M=3,55 ( $\mathrm{SD}=0,50588)$. Szczególnie nisko oceniają swoje możliwości w tym obszarze - $\mathrm{M}=2,81(\mathrm{SD}=0,87252)$.

Grupowe formy wypoczynku i rekreacji, w jakich uczestniczą członkowie rodziny to najczęściej spacery, oglądanie telewizji, zajęcia w ogrodzie, grillowanie, wyjazdy na basen, wycieczki rowerowe.

Niską wartość przypisano też interakcjom społecznym - $M=3,23$ $(\mathrm{SD}=0,84497)$. Choć satysfakcja $\mathrm{z}$ tego obszaru była nico wyższa $-\mathrm{M}=3,42$ $(\mathrm{SD}=0,50161)$, bardzo nisko oceniano jakość życia w obrębie pozostałych zmiennych: - M=3,0 i poniżej. Wszystkie badane matki twierdziły, że członkowie ich rodzin nie doświadczają żadnych form dyskryminacji w swoim otoczeniu. Przynależność do grup, klubów czy organizacji członków rodziny deklarowało zaledwie 9,6\%.

Znaczenie jakie badani przypisują poszczególnym dziedzinom życia jest najwyżej ocenianą zmienną - $\mathrm{M}=3,97(\mathrm{SD}=0,92298)$, co wskazuje, na ogólnie istotne przywiązywanie wagi do jakości życia w badanych obszarach. Wyraźnie zaznaczają się dziedziny, którym przypisuje się większe znaczenie, są nimi zdrowie, sytuacja finansowa, relacje rodzinne, wsparcie w ramach usług 
specjalistycznych. Niskie (poniżej 4,0) znaczenie przypisują pozostałym obszarom: interakcje społeczne, czas wolny i rekreacja, wsparcie ze strony innych osób, kariera zawodowa i przygotowanie do niej, system wartości.

Szansę na poprawę własnej sytuacji oceniano pesymistycznie, zwłaszcza w zakresie zdrowia - $\mathrm{M}=2,97(\mathrm{SD}=1,05647)$, usług specjalistycznych - $\mathrm{M}=2,48$ ( $\mathrm{SD}=1,36311)$, interakcji społecznych- $\mathrm{M}=2,81 \quad(\mathrm{SD}=0,87252)$ oraz rekreacji i czasu wolnego - $\mathrm{M}=2,81(\mathrm{SD}=0,87252)$. Największe możliwości dostrzegano w relacjach rodzinnych - M=3,58 ( $\mathrm{SD}=0,88597)$, choć i w tym obszarze wyniki nie przedstawiają się zbyt optymistycznie. Szanse są zmienną najniżej ocenianą przez badanych - M=2,94 (SD=1,05593), co wskazuje na ogólnie niskie spostrzeganie swoich możliwości we wszystkich badanych dziedzinach życia. Wysokie odchylenie standardowe wskazuje, że sytuacja nie jest jednorodna, są też rodziny oceniające je lepiej.

Dość wysoką inicjatywę wykazują badane rodziny w zakresie poszukiwania możliwości i wsparcia w ramach usług specjalistycznych - $M=4,32$ $(\mathrm{SD}=0,65254)$.w pozostałych obszarach są mało aktywne. W niewielkim stopniu zabiegają o wsparcie ze strony innych osób - M=2,45 ( $\mathrm{SD}=0,50588)$, o poprawę interakcji społecznych - $\mathrm{M}=2,81 \mathrm{SD}=(0,70329)$ czy karierę zawodową - $\mathrm{M}=2,97$ ( $\mathrm{SD}=1,16859)$, aczkolwiek wysokie odchylenie standardowe wskazuje, że sytuacja pod tym względem jest zróżnicowana.

Osiągnięcie jest zmienną charakteryzującą aktualnie istniejący stan funkcjonowania rodziny w badanych dziedzinach. Ogólna wartość wyników uzyskanych w tym obszarze wynosi $\mathrm{M}=3,21$ ( $\mathrm{SD}=0,83650)$, przy czym najwyżej ocenione zostały relacje rodzinne $-\mathrm{M}=4,03$ ( $\mathrm{SD}=0,65746)$ oraz wsparcie w ramach usług specjalistycznych- $\mathrm{M}=4,03$ ( $\mathrm{SD}=0,65746)$. Słabą stroną funkcjonowania rodzin są takie dziedziny życia jak: sytuacja finansowa- $\mathrm{M}=2,87$ $(\mathrm{SD}=0,34078)$, wsparcie innych osób- $\mathrm{M}=2,52$ ( $\mathrm{SD}=0,50800)$ oraz interakcje społeczne- $\mathrm{M}=2,77$ ( $\mathrm{SD}=0,66881)$. Badane matki sytuację oceniają jako stabilną, w najbliższym czasie nie oczekują jej poprawy ani też pogorszenia, na co wskazują wyniki w zakresie zmiennej stabilizacja - M=3,0.

Wynik satysfakcji (ogólnego zadowolenia) w zakresie badanych dziedzin życia wynosi $\mathrm{M}=3,49$ ( $\mathrm{SD}=0,67777)$ i jest wyższy od ogólnej wartości wyników $\mathrm{z}$ dziewięciu dziedzin $(\mathrm{M}=3,10 ; \mathrm{SD}=1,02290)$. Można zatem sądzić, że badane rodziny nie narzekają na swoją sytuację, mimo niskiej jakości życia, wyrażają ogólne wyższe, choć także niskie zadowolenie z życia.

Profile wyników sześciu zmiennych charakteryzujących badane dziedziny życia przedstawiono na wykresie 1. 
110 Dorota Otapowicz, Agnieszka Sakowicz-Boboryko, Dorota Wyrzykowska-Koda

Wykres 1. Profile średnich wyników zmiennych charakteryzujących jakość życia

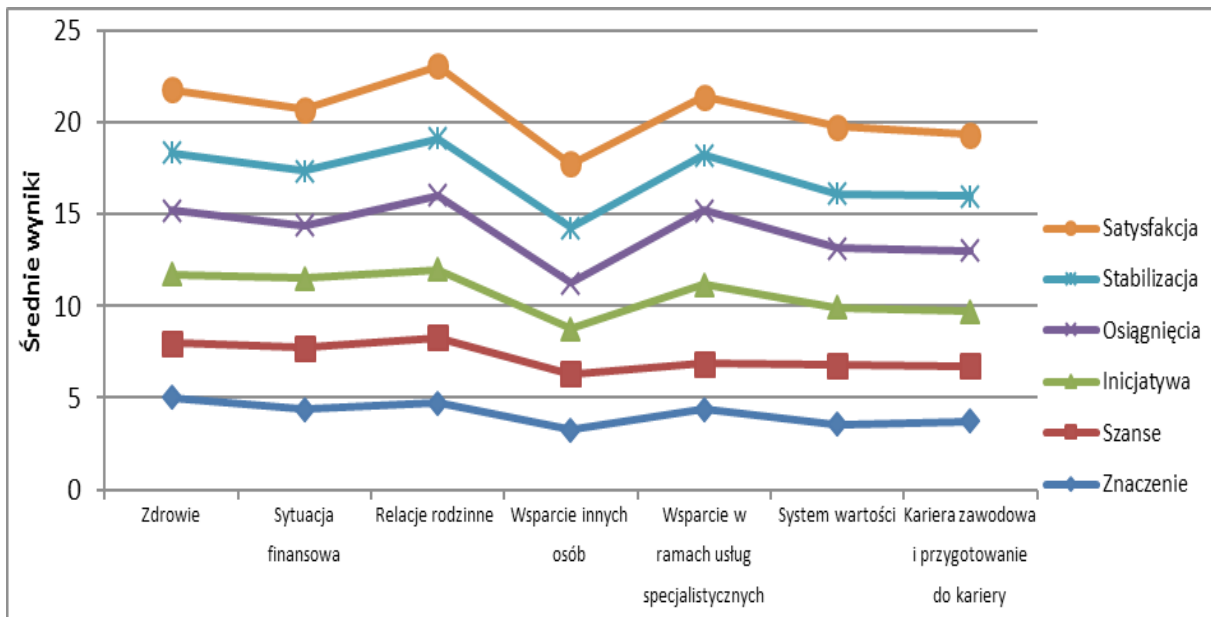

Zmienne charakteryzujące jakość życia

Podsumowując ogólny rozkład uzyskanych wyników w ramach analizowanych zmiennych charakteryzujących jakość życia badanych rodzin można zauważyć, że respondenci najwyżej oceniają relacje rodzinne i wsparcie $\mathrm{w}$ ramach usług specjalistycznych oraz wartość przypisywaną poszczególnym dziedzinom życia. Szczególnie nisko oceniają wsparcie ze strony innych osób.

\section{Omówienie wyników}

Prezentowane wyniki badań wskazują na ogólnie niskie poczucie jakości życia wśród badanych rodzin z niepełnosprawnymi dziećmi, zamieszkujących na terenie województwa podlaskiego. Świadczy o tym ogólny wynik uzyskany dla wszystkich dziewięciu dziedzin życia $(\mathrm{M}=3,1)$, przy istniejących zróżnicowaniach wykazanych za pomocą odchylenia standardowego $(\mathrm{SD}=0,93018)$. W badaniach polskich rodzin posiadających niepełnosprawnych członków zamieszkujących na obszarze miejskim uzyskane wyniki także wskazują na niską jakość życia badanych rodzin (poniżej 4,0), [Ho, James, Brown, Firkowska-Mankiewicz, Zasępa, Wołowicz, Wapiennik, 2012: 35-41]. Należy zatem stwierdzić, że mimo indywidualnych zróżnicowań w poszczególnych rodzinach, zapewne i regionach, jakość życia tej grupy rodzin wy- 
chowujących dziecko niepełnosprawne, zamieszkujących na terenie województwa podlaskiego jest niska i niższa niż jakość życia rodzin posiadających niepełnosprawnych członków rodziny zamieszkujących na obszarach miejskich Polski. Ponadto, uzyskane wyniki sugerują, że jakość życia jest niska we wszystkich badanych obszarach życia, a zwłaszcza w zakresie wsparcia ze strony innych osób i systemu wartości. Najwyżej ocenionym obszarem jest wsparcie ze strony usług specjalistycznych, lecz wynik $(M=3,52)$ wskazuje na niską jakość życia również i w tym obszarze. Trudno jest zatem o wskazanie obszarów mających pozytywne znaczenie dla jakości życia badanych rodzin; wyłaniają się natomiast obszary szczególnie deficytowe. Petrowski i wsp. [Petrowski, Edwards, Isaacs, Baum, Brown, 2008: 111-114] wskazują, że zdrowie i relacje rodzinne są oceniane wyżej od pozostałych dziedzin, najniżej - wsparcie ze strony innych osób. Taka tendencja ujawnia się także w prezentowanych wynikach badań (wykres 1), choć jak wskazywano, ogólnie są one niskie we wszystkich badanych dziedzinach.

Analizując wyniki sześciu zmiennych, najwyższy wynik dotyczy znaczenia, jakie przypisują respondenci badanym dziedzinom dla jakości życia ich rodziny. Szczególnie wysoko cenią zdrowie, nico niższe, ale także istotne znaczenie przypisują relacjom rodzinnym, usługom specjalistycznym i sytuacji finansowej. Taki stan rzeczy odnajdujemy w badaniach Petrowski i wsp. [2008], gdzie znaczenie było także oceniane wyżej niż pozostałe z sześciu zmiennych, a w szczególności zdrowie, relacje rodzinne, usługi specjalistyczne i sytuacja finansowa. Uzyskany rozkład wyników nie jest zatem swoisty, a potwierdza tendencje ujawniające się w badaniach innych autorów.

Niepokojący jest fakt, że odczuwane niedostatki w zakresie jakości życia badanych rodzin obejmują wszystkie dziedziny ich życia. Nakładające się problemy zdrowotne i finansowe rodziny rozwiązują $\mathrm{w}$ ramach własnych zasobów w postaci pozytywnych relacji rodzinnych, poszukując możliwości wsparcia ze strony usług specjalistycznych i pozyskiwania zasobów finansowych. Wydaje się, że nie biorą pod uwagę możliwości rekreacji i odpoczynku czy własnej kariery zawodowej, nie mogąc jednocześnie liczyć na wsparcie ze strony osób znajdujących się w najbliższym otoczeniu. W badaniach ogólnopolskich podkreśla się w szczególności brak wsparcia ze strony innych osób oraz sytemu usług specjalistycznych [Ho i wsp., 2012]. Doniesienia z badań rodzin australijskich wskazują na ogólne zadowolenie rodzin we wszystkich dziedzinach życia oraz całkiem dobre osiągnięcia w zakresie relacji rodzinnych, zdrowia, wartości, wypoczynku i rekreacji, przy małym wsparciu ze strony innych [Rillotta, Kirby, Shearer, 2012: 71-86]. Badania prowadzo- 
ne wśród rodzin kanadyjskich ujawniają także wysokie wyniki w zakresie ogólnej jakości życia, kariery, wartości, stosunków rodzinnych przy niskim wsparciu ze strony innych osób i usług specjalistycznych. Wskazuje się także na niskie zagospodarowanie czasu wolnego [Brown, Anand, Fung, Isaacs, 2008: 207-230]. Odnosząc się do wyników jakości życia badanych rodzin zamieszkujących na terenie województwa podlaskiego, można zauważyć, że zidentyfikowane tendencje w profilu jakości życia odpowiadają wynikom prezentowanym przez badaczy z innych regionów, przy niższym poziomie we wszystkich obszarach życia.

Całościowa analiza wszystkich badanych dziedzin jakości życia wskazuje, że niepełnosprawności dziecka skupia i ukierunkowuje dążenia, oczekiwania, wartości rodziny wokół problemów zdrowotnych. Wyrazem jest wysoka wartość przypisywana zdrowiu i usługom specjalistycznym, zaangażowanie $\mathrm{w}$ rehabilitację, często kosztem rezygnacji $\mathrm{z}$ własnej kariery zawodowej, ponoszone nakłady finansowe (nawet znaczne) mimo nie najlepszej, a czasem trudnej sytuacji finansowej. Paradoksem tej sytuacji jest naturalny niedosyt, niespełnienie się, niemożność usunięcia problemu, jakim jest fizyczna dysfunkcja organizmu. Z drugiej strony, niedoceniane i niewykorzystane pozostają te dziedziny życia, w których istnieją znacznie większe możliwości uzyskania satysfakcji i poprawy ogólnej jakości życia. To niewątpliwie potrzeba wypoczynku, rekreacji, kontaktu i nawiązywania relacji w środowisku społecznym, a tym samym pozyskiwania czy też odnajdowania naturalnych zasobów wsparcia i rozwoju osobistego każdego z członków rodziny. Wyniki badań pokazują, że formy wypoczynku i rekreacji zamykają się w obrębie rodziny, rzadko wiążą się z przynależnością do grup, klubów, organizacji, rozwijaniem osobistych zainteresowań. Wyłania się obraz rodziny skoncentrowanej na codziennych obowiązkach i zamkniętej w kręgu najbliższych osób. Choć jakość życia w dziedzinie relacji rodzinnych oceniana jest wysoko, dane jakościowe pokazują, że opierają się one raczej na podziale obowiązków niż wzajemnym pomaganiu sobie. Członkowie rodziny są niejako zdani na siebie, cenią wzajemne wsparcie i zaufanie, dość wysoko je oceniają, choć codzienna rzeczywistość to indywidualne wzmaganie się z problemami i obowiązkami. Tymczasem trudności rodziców dzieci z niepełnosprawnością w rozwiązywaniu codziennych problemów narażają ich na zespól wypalenia, charakteryzujący się stanem apatii, dystansowaniem się i chłodem w relacjach interpersonalnych [Sekułowicz, Kwiatkowski, 2013: 33]. Nasuwa się ważny wniosek: po- 
prawy jakości życia rodzin wychowujących dziecko z niepełnosprawnością należy upatrywać w normalizacji ich życia i integracji społecznej.

Ponieważ badana próba jest dość mała, uzyskane rezultaty badań traktuje się jako wstępne i sygnalizujące problem oraz wymagające ich potwierdzenia i uszczegółowienia na większej grupie. W badaniach głównymi opiekunami dzieci niepełnosprawnych były jedynie matki, choć zdarza się oczywiście, że tę rolę sprawują także ojcowie. W badaniach prowadzonych w większych grupach badawczych stwierdza się 7\% takich sytuacji [Frączek, 2013: 48-63]. Wątpliwość może budzić także znaczny odsetek rodzin pełnych, ze względu na panujący w literaturze pogląd, że niepełnosprawność dziecka może być powodem rozpadu rodzin. Tymczasem, w badaniach zazwyczaj stwierdza się niewielki odsetek rodzin niepełnych. Frączek [2013] stawia tezę, że w rodzinach niepełnych lub zrekonstruowanych wychowuje się $15 \%$ dzieci z niepełnosprawnością. Rozkład grupy jest więc zbliżony do typowych dla populacji rodzin wychowujących dziecko niepełnosprawne.

Opierając się na uzyskanych rezultatach badań, uważa się, iż w celu poprawy jakości życia badanych rodzin wychowujących dzieci niepełnosprawne, zamieszkujących na terenie województwa podlaskiego, należy:

- stwarzać możliwości dbania o zdrowie rodziny oraz poszerzać dostępną ofertę usług specjalistycznych;

- wspierać możliwości podejmowania aktywności i inicjatywę rodzin w zakresie pozyskiwania wsparcia ze strony innych osób, nawiązywania pozytywnych relacji społecznych, podejmowania kariery zawodowej i przygotowania do niej, korzystania z rekreacji i zagospodarowania czasu wolnego;

- $\quad$ wspierać możliwości poprawy sytuacji w sferze finansowej.

\section{Wnioski}

1. Jakość życia rodzin wychowujących dziecko niepełnosprawne, zamieszkujących na terenie województwa podlaskiego, jest niska we wszystkich dziedzinach życia.

2. Dokonana analiza jakości życia może stanowić wstępny punkt wyjścia do poszukiwania praktycznych rozwiązań wspierania rodzin wychowujących dziecko niepełnosprawne. 
114 Dorota Otapowicz, Agnieszka Sakowicz-Boboryko, Dorota Wyrzykowska-Koda

3. Potrzebne są dalsze badania i pogłębione analizy z wykorzystaniem danych jakościowych, które pozwolą na pełniejsze rozpoznanie sytuacji i ukierunkowanie oddziaływań wspierających.

\section{Bibliografia}

Brown I., Brown R. I., Baum N. T., Isaacs B. J., Myerscough T., Neikrug S., Roth D., Shearer J., \& M. Wang (2006), Family Quality of Life Survey: Main caregivers of people with intellectual or developmental disabilities, tłum. E. Zasępa, E. Wapiennik, A. Wołowicz, Toronto, ON, Canada: Surrey Place Centre.

Dziurowicz-Kozłowska A. (2002), Wokół pojęcia jakość życia, „Psychologia Jakości Życia”, nr 1.

Firkowska-Mankiewicz A. (1999), Jakość życia rodzin z dzieckiem niepełnosprawnym, „Psychologia Wychowawcza”, nr 2.

Frączek P. (2013), Rodziny wychowujące dzieci z niepetnosprawnością $i$ ich oczekiwania wobec polityki społecznej, „Wrocławskie Studia Politologiczne”, nr 15.

Ho E., James N., Brown I., Firkowska-Mankiewicz A., Zasępa E., Wołowicz A., Wapiennik E. (2013), Family Quality of Life of Polish Families with a Member with Intellectual Disability, "Journal of Intellectual Disability Research", nr 19(2).

Kawczyńska-Butrym Z. (1994), Problemy wspierania rodzin z osobami niepelnosprawnymi, (w:) A. Ostrowska (red.), Badania nad niepełnosprawnościa w Polsce 1993, Warszawa, IFiS PAN.

Majkowicz M., Nowicki R., Samet A., Żelazny I. (2004), Jakość życia w chorobach skóry, „Przewodnik Lekarza”, nr 9.

Ostrzyżek A., Marcinkowski J.T. (2012), Quality of life as a positive health index, "Hygeia Public Health", nr 47(4).

Petrowski N. T., Edwards M., Isaacs B. J., Baum N., Brown I. (2008), Family Quality of Life: Preliminary Analyses From an On-going Project, "Journal of Intellectual Disability Research", nr 14(2).

Rillotta F., Kirby N., Shearer J., Nettelbeck T. (2012), Family quality of life of Australian families with a member with an intellectual/developmental disability, "Journal of Intellectual Disability Research", nr 56(1).

Sadowska S. (2006), Jakość życia uczniów z niepetnosprawnościa intelektualna $w$ stopniu lekkim, Kraków, Oficyna Wyd. „Impuls”.

Samuel P. S, Rillotta F., Brown I. (2012), The development of family quality of life concepts and measures, "Journal of Intellectual Disability Research", nr 56.

Sekułowicz M., Kwiatkowski P. (2013), Wypalanie się sił u rodziców dzieci z niepełnosprawnościa - konstrukcja nowego narzędzia badawczego, „Studia Edukacyjne”, nr 25.

Syrek E. (red.) (2001), Jakość życia w chorobie, Kraków, Oficyna Wyd. „Impuls”.

Tobiasz-Adamczyk B. (2000), Wybrane elementy socjologii zdrowia i choroby, Kraków, Wydawnictwo Uniwersytetu Jagielońskiego. 
SUMMARY

\section{Disability and Family Quality of Life}

In the ecosystem perspective of family life, disability is not a problem only focused on the child but it affects the whole family in all its functions and dimensions of existence. It also determines the quality of life of the family that undertakes to raise a disabled child. The work involves evaluation of the quality of life of families raising disabled children residing in the territory of Podlaskie Voivodeship. The Polish version of Family Quality of Life Survey (by I. Brown et al., translated by: Zasępa E, Wapiennik E, Wołowicz A, 2006) was used in the research. Both strengths and deficits resulting from the analysis of findings of the research on family quality of life were pointed out in the work. They were then used to identify the needs of practical support for the families.

\section{Keywords:}

disability, family, quality of life 